\title{
Bibliometry of marine science and limnology publications (1979-2015) by the Centro de Investigación en Ciencias del Mar y Limnología (CIMAR), Universidad de Costa Rica
}

\author{
Vanessa Nielsen-Muñoz ${ }^{1}$, Ana Beatriz Azofeifa-Mora ${ }^{2}$, Raquel Romero-Chaves ${ }^{3}$ \\ \& Ingo S. Wehrtmann ${ }^{3,4}$ \\ 1. Revista de Biología Tropical, Universidad de Costa Rica, 11501-2060 San José, Costa Rica; \\ vanessa.nielsen@ucr.ac.cr \\ 2. Escuela de Bibliotecología, Documentación e Información, Universidad Nacional, Heredia, Costa Rica; \\ beatriz.azofeifa.mora@una.cr \\ 3. Unidad de Investigación Pesquera y Acuicultura (UNIP) of the Centro de Investigación en Ciencias del Mar y \\ Limnología (CIMAR), Universidad de Costa Rica, 11501-2060 San José, Costa Rica; \\ raquelromerochaves@gmail.com, ingo.wehrtmann@ucr.ac.cr \\ 4. Escuela de Biología, Universidad de Costa Rica, 11501-2060 San José, Costa Rica
}

Received 25-V-2017. Corrected 02-XI-2017. Accepted 03-I-2018.

\begin{abstract}
Bibliometrics play a significant role in evaluating the scientific production of journals and research units such as universities and research centers. The present study aimed to analyze the scientific production of CIMAR (Center for Research in Marine Science and Limnology) from its foundation in 1979 to 2015. We analyzed exclusively articles published in journals and selected those with at least one author affiliated to CIMAR. For the analysis, each article was classified according to the geographical study area, the topic of the investigation, ecosystem, and taxonomic group. We analyzed the following variables: year of publication, language, journal name, and authors. In this study, we analyzed the Bradford distribution, citations, the impact factor, and the quartiles of the journals where papers were published. During the study period, CIMAR produced a total of 791 publications: 624 articles, 90 book chapters or books, 48 booklets, and 34 special issues of the journal Revista de Biología Tropical (RBT). The number of publications showed an increasing trend during the study period, and most articles were written in English (58.3\%) and Spanish (41.7\%). A total of 128 journals were selected to publish CIMAR's contributions. According to the Bradford method, the journal RBT is in Zone I (major productivity or concentration), with $49.8 \%$ of the total scientific production. In relation to authorship, 22 authors with 12 articles or more are registered, and $80 \%$ of the articles have been published by authors with a low (42 authors) and medium productivity level (44 authors). CIMAR published $81.6 \%$ regarding marine topics and $18.4 \%$ about limnology. Most of the articles (51.9\%) dealt with the Pacific of Costa Rica, $13.5 \%$ with the Caribbean and $34.7 \%$ referred to other study locations. The publications of CIMAR were mainly about ecology (33.3\%), taxonomy (24.5\%) and oceanography/meteorology (12.7\%). CIMAR has a highly trained and specialized staff that has gained experience and is contributing to the implementation and evaluation of Costa Rica's science, technology and innovation policies through both interdisciplinary research and the development of institutional as well as professional capacities in a framework of dialogue and public-private agreements. Rev. Biol. Trop. 66(Suppl. 1): S1-S23. Epub 2018 April 01.
\end{abstract}

Key words: bibliometry, author productivity, scientometric analyses, Costa Rica, CIMAR, Collaboration Index, research topics, citations, Latin America.

Bibliometrics play a significant role in evaluating the scientific production of journals and research units such as universities and research centers (Russell, Ainsworth, del Río, Narváez-Berthelemot, \& Cortés, 2007; Butler,
2008; De Filippo, Córdoba-González, \& SanzCasado, 2016). This type of studies provide valuable information about scientific activities, such as national, regional and international cooperation, diversity and importance of 
research topics, productivity, as well as interactions between researchers (Fernández, Gómez, \& Sebastián, 1988; Russell et al., 2007; Bornmann, Mutz, Neuhaus, \& Daniel, 2008). There is, however, a consensus that measuring science and scientific productivity is an extremely difficult or even impossible task (see Giske, 2008 and reference therein) and some argue that these measurements are crude and may harm science (Lawrence, 2008 and references therein). On the other hand, quantitative performance indicators such as bibliometrics are needed to assess research (e.g., Butler, 2008).

Several scientometric analyses have been applied to assess scientific productivity in Latin America. Tinoco, Lima, Lima-Ribeiro, \& Collevatti (2015) analyzed research and partnerships regarding studies on population genetics of Neotropical plants, while numerous bibliometric studies focused on agricultural (Saavedra-Fernández, Sotolongo-Aguilar, \& Guzmán Sánchez, 2002; De Arenas, Arenas, $\&$ Valles, 2002) and health sciences (Chiroque \& Medina, 2003; Chinchilla-Rodríguez, Benavent-Pérez, \& de Moya-Anegón, 2012; VeraPolania et al., 2014; Colantonio, Baldridge, Huffman, Bloomfield, \& Prabhakaran, 2015). Regarding biological topics, Michan, Michán, \& Llorente-Bousquets (2010) conducted a bibliometric study on biological systematics and taxonomy in Latin America, while Medina \& Páramo (2014) revised environmental education in Latin America. Lima, Velho, \& Faria (2007) analyzed the international scientific cooperation in bioprospection. Costa Rica can be considered as a well-documented country in terms of bibliometric studies regarding biological subjects (Lomonte \& Ainsworth, 2002; Monge-Nájera \& Nielsen, 2005; MongeNájera, Nielsen-Muñoz, \& Azofeifa, 2010; Lomonte, 2012; Monge-Nájera \& Ho, 2012; Nielsen-Muñoz, Azofeifa-Mora, \& MongeNájera, 2012; Monge-Nájera, Nielsen-Muñoz, \& Azofeifa-Mora, 2013; Monge-Nájera \& Ho, 2016; De Filippo, Córdoba-González, \& SanzCasado, 2016).

A few bibliometric studies evaluated the scientific productivity regarding marine topics.
Araújo \& Shideler (2011) examined 4303 papers and notes published between 1951 and 2010 in the journal Bulletin of Marine Science to trace the history and status of the journal. Fourqurean, Duarte, Kershaw, \& Threlkeld (2008) used also a bibliometric approach to analyze scientific contributions published in the journal Estuaries and Coasts. Wulff (2008) revised the databases of Web of Knowledge (WOK) and Aquatic Sciences and Fisheries Abstracts (ASFA) to evaluate publications in marine botany. Cortés \& Nielsen (2002) carried out an analysis of contributions related to marine science published in the journal Revista de Biología Tropical (RBT) during its 50 years of existence; most of the 637 contributions published between 1963 and 2002 dealt with coral reefs and fishes. Nielsen-Muñoz, Azofeifa-Mora, \& Monge-Nájera (2012) analyzed the papers published in RBT about biodiversity during the decade of 2000-2010, which included several publications of Centro de Investigación en Ciencias del Mar y Limnología (CIMAR). The present study focuses on the productivity of CIMAR, analyzing the publications of all research topics since its foundation in 1979 and includes not only those paper published in RBT but also those published in other (national and international) journals. As far as we know, this is the first published study on the scientific production of a Latin American research center focusing on marine biology and limnology.

The CIMAR (http://www.cimar.ucr.ac.cr/ cimar/sobre-cimar.html) is a multidisciplinary scientific research unit attached to the ViceRectory of Research of the University of Costa Rica (UCR). CIMAR has been conducting research on aquatic ecosystems in Costa Rica since 1979 , focusing on aquatic biodiversity and processes associated with its sustainable management, including the evaluation of environmental pollution, environmental impact studies, the exploration of non-traditional resources, and fishery-related studies, among others. Research has been carried out in various aquatic ecosystems such as coral reefs, mangroves, soft and hard bottoms, seagrass beds, 
pelagic ecosystems (including plankton), deepwater systems, and freshwater environments (lakes, rivers and reservoirs) in Costa Rica. Moreover, CIMAR researchers are studying oceanographic and climatic processes associated with marine environments.

The present study aimed to analyze the scientific production of CIMAR in the field of marine science and limnology, on the occasion of the celebration of over one thousand contributions of this center since its foundation in 1979. The obtained results may provide important insights in research tendencies in Costa Rica and the Central American region during the last decades.

\section{MATERIAL AND METHODS}

The CIMAR produced between 1979 and 2015 a total of 791 publications. From these, 624 were articles published in journals, 90 were book chapters or books, 48 were booklets, and the remaining 34 productions correspond to special issues of the RBT, with at least one scientist affiliated to CIMAR as editor. In the present study, we analyzed exclusively articles published in journals and selected those with at least one author affiliated to CIMAR. As principal source for the literature search we used the "Lista de Publicaciones del CIMAR" (available at http://www.cimar.ucr.ac.cr/en/ publications.html) and the "Bibliografía sobre la producción científica del CIMAR 2006" edited by the Organization for Tropical Studies (OTS) (http://www.ots.ac.cr/images/downloads/information-resources/library/cimar.pdf). The references of the selected publications with affiliation of CIMAR were transferred into a database (ProCite 5.0) for subsequent bibliometric analysis of the following variables: (1) year of publication, (2) language, (3) journal name, and (4) authors.

The Bradford distribution (Leimkuhler, 1967; Praunlich \& Kroll, 1978) was applied to identify the journals used by the researchers of CIMAR for their publication. This distribution organizes journals according to the number of articles in three zones, where each zone contains approximately $33.33 \%$ of the articles. The nuclear group (Zone I) of journals is the one with the highest concentration of published articles; the first third of journals have the highest impact. To complement the results obtained from the model on concentration and dispersion of the published articles, the Index of Density of Articles was applied (Zakutina \& Priyenikova, 1983) to obtain an average number of articles per title (journal) in each one of the zones.

The variable "authorship" was evaluated by the Collaboration Index (see Gorbea, 2005), one of the most utilized indicators to study the behavior of authors, which indicates the average signature. Moreover, the Productivity Index (PI), based on Lotka (PI logarithm of the number of original articles) was applied to classify the authors into three levels of productivity: low: with 1 item and a PI equal to zero, medium: 2 to 9 items with PI zero and less than 1, and high producers: 10 or more items with PI greater than 1 (Spinak, 1996).

The Web of Science - Journal Citation Report was consulted through the System of Libraries, Documentation and Information (SIBDI) of the UCR, which allowed us to extract the impact factor and the quartiles of journals used for the publications of CIMAR. The affiliations were used as indicated in the original publications. Four articles with more than 17 authors were not included in our analysis because the participation of CIMAR was only marginal. Moreover, and considering the high number of authors from different institutions and countries, the inclusion of these four publications would have distorted the analyses of CIMAR-collaboration.

For the analysis of the research theme, each article was classified according to the geographical study area and the topic of the investigation. The following classifications were used (1) marine or limnological study; (2) Pacific, Caribbean or others (limnological studies and other countries); if the study was carried out in both coasts we counted one in each category; (3) area of focus: Golfo de Nicoya, Golfo Dulce, Isla del Coco and others 
(limnological studies, Caribbean coast, other zones of the Pacific and other countries); (4) type of ecosystem: coral reef, benthos, estuary, mangroves, pelagic or others (limnology, physical and chemical studies); (5) taxonomic group: algae, animals, plants and others (Protozoa); (6) vertebrates, invertebrates or others (not related to animals); (7) principal topic of the study: ecology, chemistry, oceanography and meteorology, fishery, taxonomy, and others (any other topic).

In the case of the principal topic of the study (Classification 7), each one of the 624 articles analyzed was assigned to only one of the proposed categories. However, considering that in the Classifications 1 to 6 each paper may be included in one, several or none of the categories, the total count of articles may deviate from the total of 624 articles analyzed. To avoid confusions regarding the total counts used in the analysis of the articles, in Classifications 1 to 6 the term "case" was applied instead of "article", so the numbers of "cases" in these classifications are more or less than 624 , the number of analyzed papers. Once the classification for each publication was defined, we analyzed the percentage of articles (Classification 7) or cases (Classifications 1 to 6) for each category for the 36 years of research activity of CIMAR and for following three time periods: 1980's (1979-1989), 1990's (1990$2000)$ and 2000's (2001-2015). For each time period, only articles published in the years of the analyzed periods were considered.

\section{RESULTS}

\section{Year of publication}

During the first decade (1979-1989) after the foundation of CIMAR, a total of 101 contributions were published, 125 in the second decade (1990-2000) and 398 between 2001 and 2015. The number of publications showed an increasing trend during the study period (19792015) (Fig. 1).

\section{Language and journals}

Most of the articles published between 1979 and $2015(\mathrm{~N}=624)$ were written in English $(58.3 \%)$, while 260 papers were written in Spanish (41.7\%).

A total of 128 different journals were used to publish the contributions of the CIMAR. According to the Bradford method, the journal RBT is in Zone I or of major productivity (concentration), comprising 311 articles, which corresponds to $49.8 \%$ of the total scientific production of CIMAR (Table 1). Zone II consists of 52 journal titles including Brenesia with 20 articles, Zootaxa with 19, Tópicos Meteorológicos y Oceanográficos with 14, Bulletin of Marine Science with 12, and Marine Biology with 10 contributions. The remaining 47

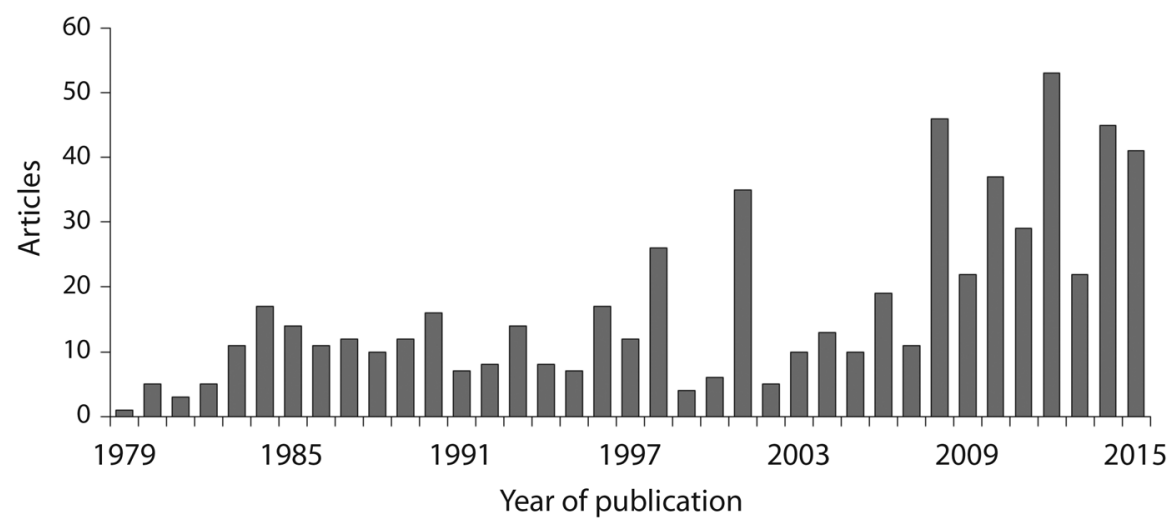

Fig. 1. Number of articles per year (1979-2015) from authors affiliated to CIMAR. 
TABLE 1

Concentration-dispersion of the 624 articles of CIMAR published in 128 journals according to the method proposed by Bradford (see Leimkuhler, 1967; Praunlich \& Kroll, 1978)

\begin{tabular}{|c|c|c|c|c|c|}
\hline Zone & \# of journals & $\%$ of journals & Number of articles & $\%$ of articles & Density Index \\
\hline I & 1 & 0.8 & 311 & 49.8 & 311 \\
\hline II & 52 & 40.6 & 238 & 38.1 & 4.6 \\
\hline III & 75 & 58.6 & 75 & 12.0 & 1 \\
\hline Total & 128 & 100 & 624 & 100 & \\
\hline
\end{tabular}

journal titles contributed with 2 to 9 articles. Zone III or of less productivity (dispersion) is composed by 75 journal titles with one publication per journal. The Index of Density revealed even more the level of concentration-dispersion of the publications per zone: A high concentration in Zone I means that a smaller number of journals is required to achieve $33.33 \%$ of the articles, and therefore shows the dominance of RBT (Table 1).

According to the Journal Citation Report (JCR), RBT is in the fourth quartile. Of the 52 journals comprising Zone II, the following journals are in the first quartile: Marine Biology, Coral Reefs, Fisheries Research, Marine Pollution Bulletin, PLoS ONE, Hydrobiologia, Journal of Biogeography, Water Research, and Zoological Journal of the Linnean Society. The following journals are in the second quartile: Journal of Experimental Marine Biology and Ecology, Marine Ecology Progress Series, Estuarine, Coastal and Shelf Science, and Journal of Fish Biology. The third quartile is composed by 10 journals, the fourth quartile by nine journals. The remaining 20 journals are not associated to any quartile of the JCR.
Zone III (of minor productivity) contains 75 publications; 15 of these are in the first quartile: Biomass and Bioenergy, Current Biology, Ecology, Geochimica et Cosmochimica Acta, Global Ecology and Biogeography, International Journal of Climatology, Journal of Animal Ecology, Journal of Hydrology, Journal of Phycology, Limnology and Oceanography, Nature, PeerJ, PLoS ONE, Proceedings of the Royal Society B Biological Sciences, and Science. A total of 13 journals can be found in the second quartile, 11 in the third quartile, five form part of the fourth quartile, while 31 journals are without any quartile assignation (Table 2).

A total of 85 journal titles (64.1\%) were published in journals managed by scientific societies, universities, research centers, and institutes. Commercial publishers such as Elsevier, Springer, Academic Press, among others, represented $33.6 \%$ of the published journal titles. The majority of the articles (61.9\%) were published in Costa Rican journals, followed by those published in USA $(9.8 \%)$ and Germany (5.6 \%) (Appendix 1).

TABLE 2

Distribution of the journals and publications used by authors affiliated with CIMAR according to the quartiles indicated in the Journal Citation Report

\begin{tabular}{ccccc} 
Quartile & Journal & \% of journals & Articles & \% of articles \\
1 & 24 & 18.8 & 47 & 7.5 \\
2 & 17 & 13.3 & 27 & 4.3 \\
3 & 21 & 16.4 & 78 & 12.5 \\
4 & 15 & 11.7 & 342 & 54.8 \\
Without assignation & 51 & 39.8 & 130 & 20.8 \\
Total & 128 & 100 & 624 & 100 \\
\hline
\end{tabular}




\section{Authorship and productivity of authors}

A total of 108 authors were identified with an affiliation of CIMAR, including permanent researchers of CIMAR as well as thesis students, interns, and collaborating researchers. Considering the productivity (number of articles per author), the authors were grouped into three levels (high - medium - low; see Spinak, 1996). The most productive authors during the study period were Jorge Cortés-Núñez, Eric J. Alfaro-Martínez, José Antonio Vargas-Zamora, Ingo S. Wehrtmann, and William A. Bussing (Appendix 2).

A total of 22 authors with a CIMARaffiliation published 10 or more articles and 80 $\%$ of the total publications have been published by authors with a low (42 authors) and medium productivity level (44 authors), including both CIMAR-researchers and other colleagues temporary associated to the center (Table 3 ).

\section{Collaboration}

The rate of co-authored articles was 0.78 and the Collaboration Index or average number of authors per publication was 2.70 (Table 4). A total of $22.4 \%$ of the articles were written by one single author, $34.7 \%$ by two, $19.7 \%$ by three, and $13.5 \%$ by four or more authors.

Regarding the international collaboration of the publications of CIMAR, a total of 267 articles $(42.8 \%)$ indicated foreign affiliations; 326 authors from 221 institutions belonging to 35 countries were identified. The most frequent collaborations were with researchers from USA and Germany, followed by Panama (mostly due to the cooperation with the Smithsonian Tropical Research Institute) and Mexico (mainly with the Centro de Investigación Científica y de Educación Superior de Ensenada, Baja California, and the Instituto de Ciencias del Mar y Limnología of the Universidad Nacional

TABLE 3

Productivity levels of the authors with CIMAR affiliation, University of Costa Rica

\begin{tabular}{ccccc} 
Number of published articles & Level of productivity & Number of authors & Productivity Index & $\%$ \\
$2-9$ & low & 42 & 0 & 38.9 \\
$10+$ & medium & 44 & $>0$ y 1 & 40.7 \\
& high & 22 & $\geq 1$ & 20.4 \\
& Total & 108 & & 100 \\
\hline
\end{tabular}

TABLE 4

Number of authors per article with CIMAR affiliation, University of Costa Rica (up to 15 authors)

\begin{tabular}{cccc} 
Number of authors & Number of articles & Total number of authors & \% authors \\
1 & 139 & 139 & 8.3 \\
2 & 215 & 430 & 25.7 \\
3 & 122 & 366 & 20.1 .9 \\
4 & 84 & 336 & 6.6 \\
5 & 22 & 110 & 4.7 \\
6 & 13 & 78 & 4.2 \\
7 & 10 & 70 & 3.4 \\
8 & 7 & 56 & 1.6 \\
9 & 3 & 27 & 0.6 \\
10 & 1 & 10 & 1.3 \\
11 & 2 & 22 & 0.8 \\
15 & 1 & 14 & 0.9 \\
Total & 1 & 15 & 100 \\
\hline
\end{tabular}


Autónoma de México, among others) (Appendix 3). Regarding the national collaboration of the analyzed CIMAR-documents, a total of 60 articles $(9.6 \%)$ showed authors of 38 Costa Rican institutions (private organizations, nongovernmental organizations, ministries, autonomous institutions, public universities, among others) (Appendix 4).

A total of 112 articles $(18.0 \%)$ were co-authored with colleagues from other departments of the UCR. The most important collaboration within the University of Costa Rica was with the Escuela de Biología (308 articles; $48.4 \%$ ) (Appendix 5). In 417 articles (66.8\%) CIMAR-associated author indicated between two and four additional affiliations.

\section{Research topics}

During the 36 years of research activity of CIMAR, the center published $81.6 \%$ regarding marine topics and $18.4 \%$ on limnology. During all three time periods analyzed the number of documents published about the marine realm was consistently higher than publications about limnology (Fig. 2). Most of the articles (355 cases; $51.9 \%$ ) dealt with the Pacific of Costa Rica, $13.5 \%$ (92 documents) with the Caribbean, and $34.7 \%$ (237 documents) referred to other study locations (Fig. 3), such as foreign countries.

The most-studied location on the Pacific of Costa Rica was Golfo de Nicoya (11.0 \%),

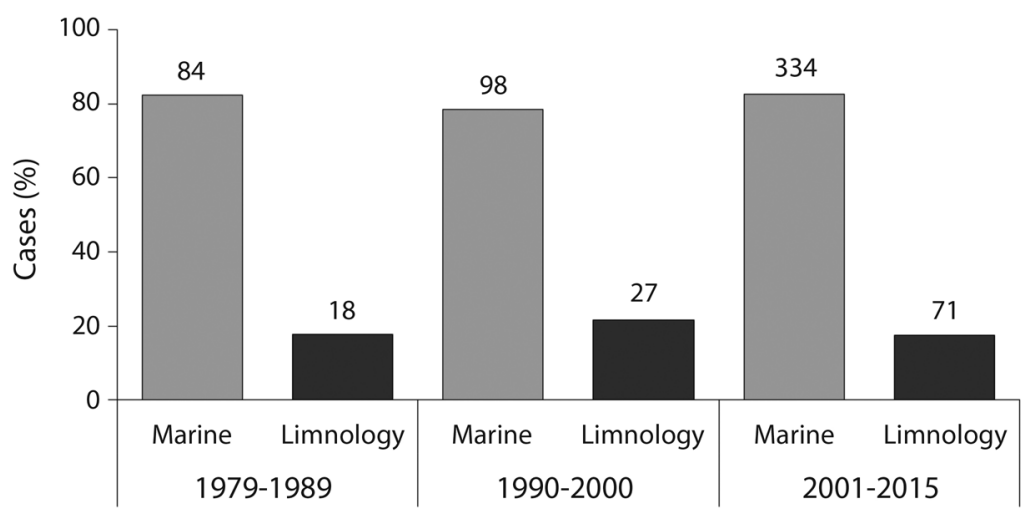

Fig. 2. Marine versus limnology studies: percentage distribution during the three time periods analyzed between 1979 and 2015. The number of papers is indicated on top of each column.

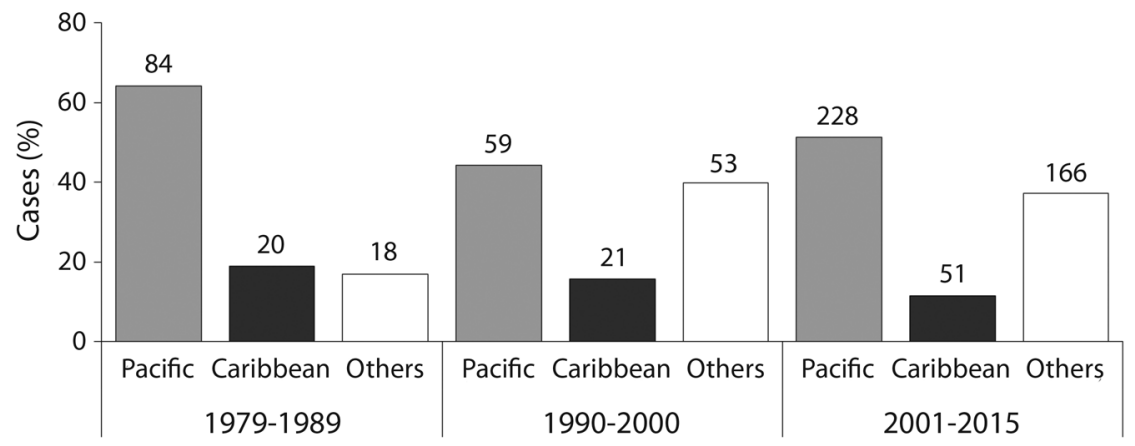

Fig. 3. Percentage of cases published per period analyzed (1979-2015) regarding the Pacific and Caribbean of Costa Rica. The number of papers is indicated on top of each column. 
followed by Isla del Coco (8.7 \%), Golfo Dulce $(5.3 \%)$, and Isla del Caño $(1.1 \%)$. A total of $73.9 \%$ of the cases referred to studies about other locations (other areas along the Pacific coast of Costa Rica, other countries, Caribbean coast, etc.). Studies on the Golfo de Nicoya were predominant in the 1980's and 1990's, while publications about Isla del Coco were most numerous in the 2000's when compared to the other three main study areas along the Pacific of Costa Rica. On the other hand, studies on Golfo Dulce were absent in the 1980's and articles were published only during the two more recent time periods analyzed (Fig. 4).

When analyzing the type of ecosystem or habitat of studied species mentioned in the articles of CIMAR, a total of 219 cases referred to the benthos, coral reefs, pelagic systems, mangroves, and estuaries (Fig. 5). The remaining $35.7 \%$ of the cases were about other systems. The predominance of published studies about the benthos and coral reefs was noticeable during all three time periods analyzed (Fig. 5).

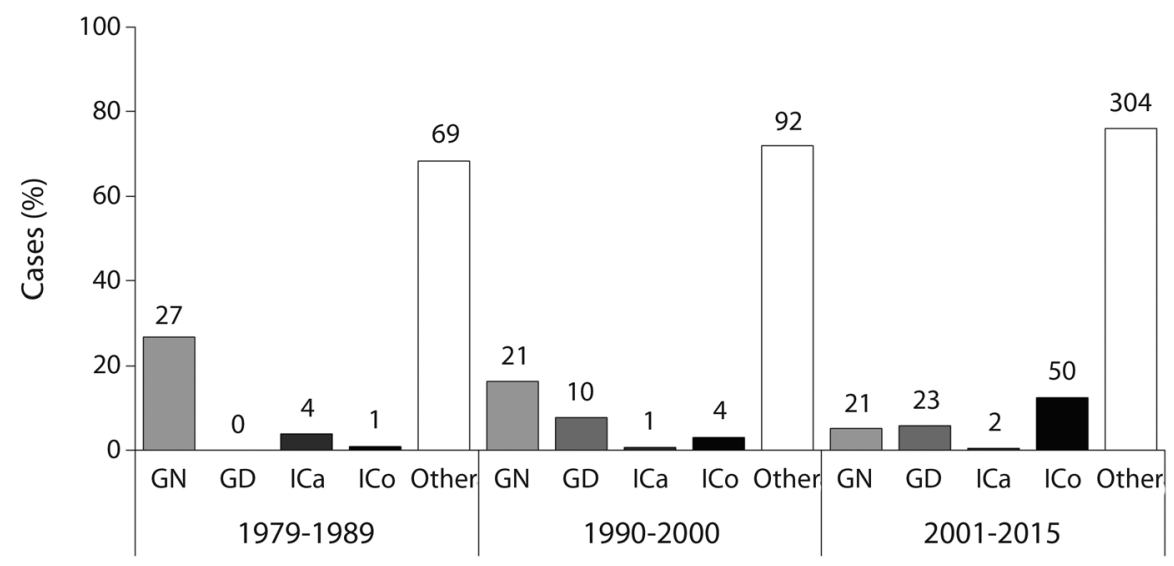

Fig. 4. Percentage of cases published by CIMAR, Universidad de Costa Rica, in the main study areas (GN $=$ Golfo de Nicoya, $\mathrm{GC}=$ Golfo Dulce, Ica = Isla del Caño, ICo = Isla del Coco) and during the three time periods (1979-2015) analyzed. Number of papers is indicated on top of each column.

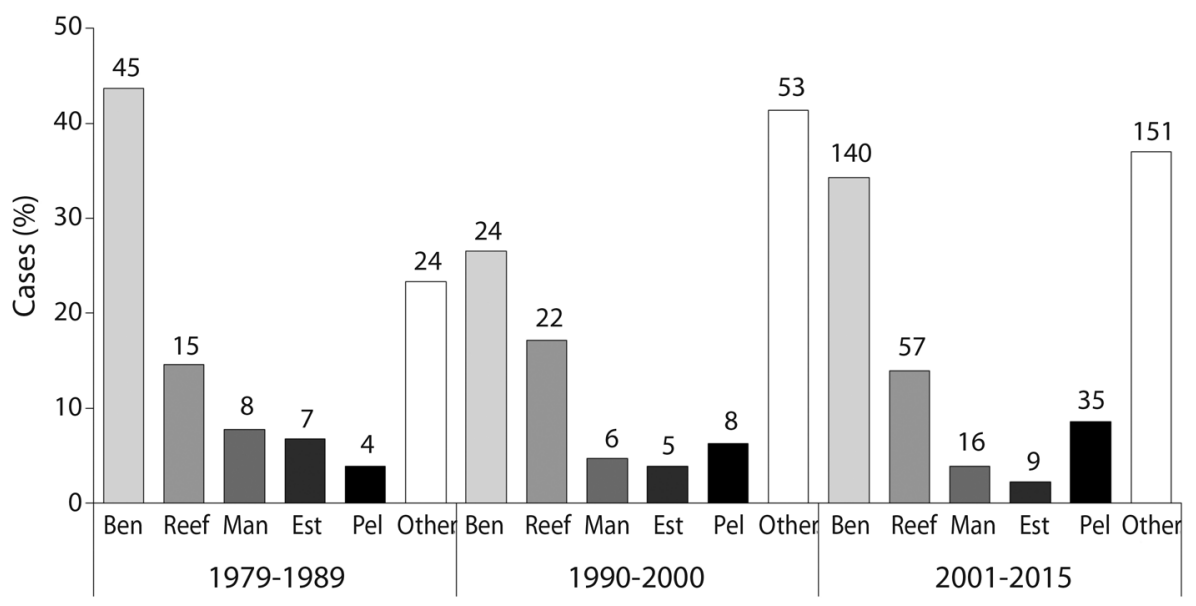

Fig. 5. Percentage of cases published by CIMAR regarding different ecosystems or habitats $($ Ben $=$ benthos, Reef $=$ coral reefs, Man = mangroves, Est $=$ estuaries, $\mathrm{Pel}=$ pelagic systems $)$ and during the three time periods (1979-2015) analyzed. The number of papers is indicated on top of each column. 
Regarding the taxonomic groups of the published documents by CIMAR, studies about animals comprised $61.2 \%$, while those regarding algae, plants and others were less numerous; this tendency was similar in all three time periods analyzed (Fig. 6). A total $23.9 \%$ of the articles were about other organisms like bacteria or protozoans. In the case of documents about animals, most of the publications referred to invertebrates (334 cases; 78.0\%) followed by vertebrates (94 cases; $22.0 \%$ ). This trend was maintained during the three time periods analyzed.

Overall and considering the entire period (1979-2015), publications of CIMAR referred mainly to studies on ecology (208 articles; $33.3 \%)$, taxonomy $(153 ; 24.5 \%)$ and oceanography/meteorology $(79 ; 12.7 \%)$. During the last two periods, topics such as limnology and oceanography/meteorology increased in importance (Fig. 7).

\section{Citations}

According to Web of Science, a total of $65.7 \%$ of the articles published by CIMAR were cited once or more; $10.1 \%$ were not cited, and $24.2 \%$ of the published documents were not listed in the database of Web of Science (Appendix 6). Table 5 presents articles with more than 100 cites (authors of CIMAR in bold).

\section{DISCUSSION}

\section{Publication per year}

The number of publications of CIMAR increased constantly during the three time periods analyzed, especially during the last years (2001-2015), when three-times more contributions were published compared to the other two earlier time periods. This increase may be related to an increasing number of affiliated researchers, undergraduate and graduate students, and collaborators. On the other hand, highly productive researchers continue to produce a relative high number of publications per year, but also the incorporation of young productive colleagues as CIMAR-staff members contributed to the increasing number of scientific publications. Moreover, the peaks of productivity correspond to the publication of special supplements of the RBT for the years 1998, 2001, 2008, 2012, and 2014. In these years the percentages of papers included in special supplementes were: 92.3, 80.0, 73.9, 60.4, and $26.7 \%$, respectively (for details of supplements: https://revistas.ucr.ac.cr/index.php/rbt/ issue/archive?issuesPage=2).

\section{Language and journals}

There are no studies about the language of publications of research centers in Latin

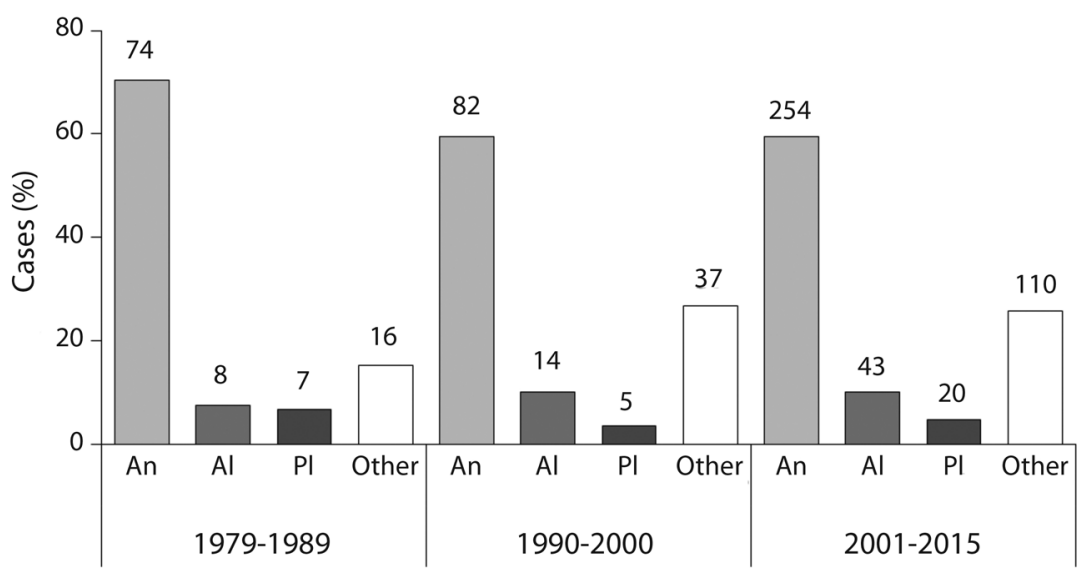

Fig. 6. Percentage of cases published by CIMAR regarding taxonomic groups $(\mathrm{An}=\mathrm{Animal}, \mathrm{Al}=\mathrm{Algae}, \mathrm{Pl}=\mathrm{Plants})$ and during the three time periods (1979-2015) analyzed. The number of papers is indicated on top of each column. 


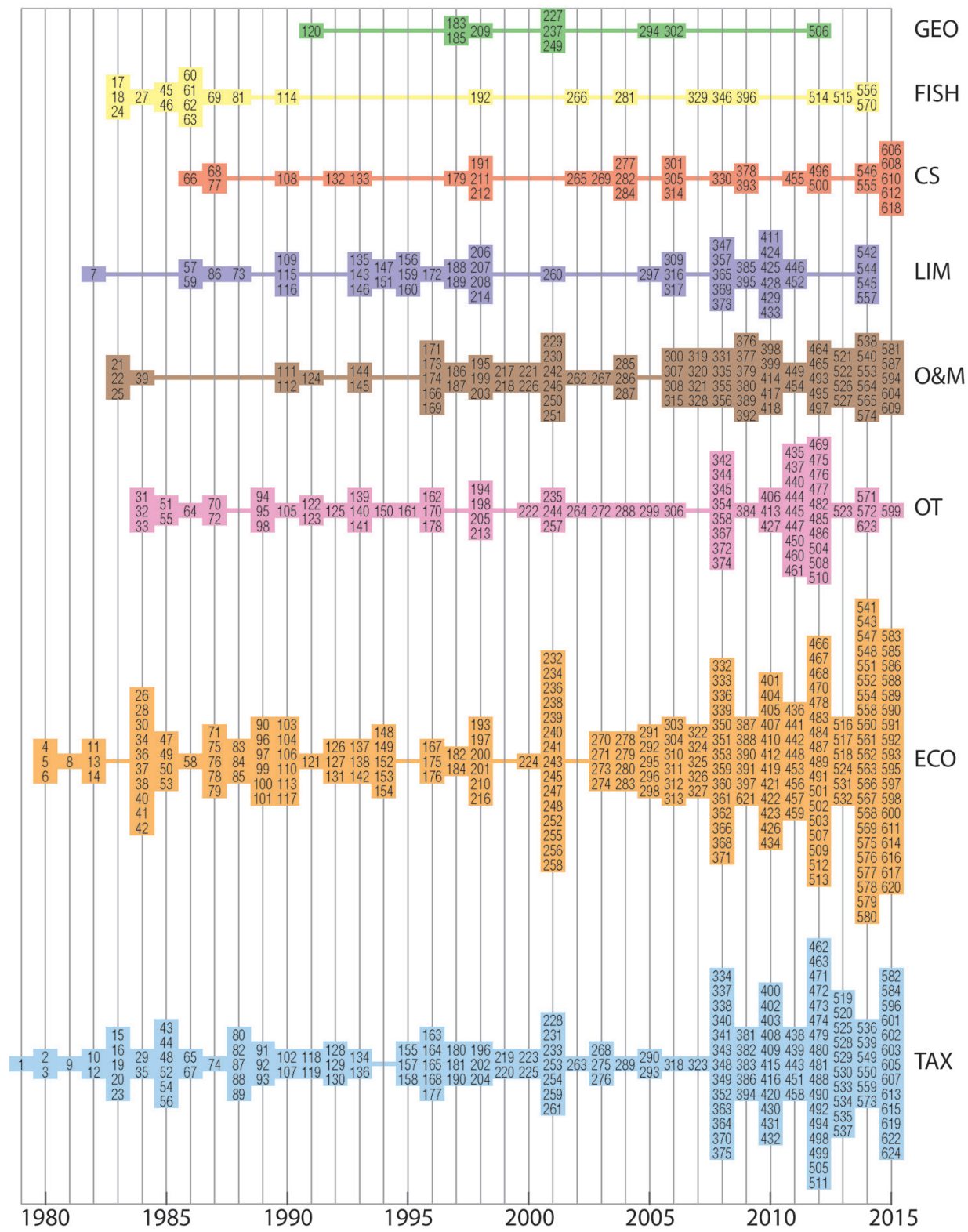

Fig. 7. Published articles by CIMAR, listed by topic $(\mathrm{Tax}=$ Taxonomy, Eco $=$ Ecology, OT $=$ Other, O\&M = Oceanography and Meteorology, LIM = Limnology, CS = Chemical studies, FISH = Fisheries, GEO = Geology) and year (1979-2015). The numbers indicated refer to the consecutive numbers of the published documents.

America; however, in general, English is clearly the predominant language for publications included in Biological Abstracts (MongeNájera \& Nielsen, 2005). These authors showed that the English language predominated in publications on systematic topics in Latin America during the 20th century.
In the Biosis database, most documents $(72.4 \%)$ were published in English, 13.2 $\%$ in Spanish, $9.6 \%$ in Portuguese. In CAB (bibliographic databases) the percentages were 58, 20 and $12 \%$, and in the Science Citation Index (SCI) 88.8, 6.5 and $3.6 \%$, respectively (Michán \& Llorente-Bousquets, 2010). 
TABLE 5

Articles with more than 100 cites. The name of authors in bold represent CIMAR-associated researchers

$$
\text { Article }
$$

Carpenter, K. E., M. Abrar, G. Aeby, R. B. Aronson, S. Banks, A. Bruckner, A. Chiriboga, Jorge Cortés-Núñez, J. C. Delbeek, L. DeVantier, G. J. Edgar, A. J. Edwards, D. Fenner, H. M. Guzman, B. W. Hoeksema, G. Hodgson, O. Johan, W. Y. Licuanan, S. R. Livingstone, E. R. Lovell, J. A. Moore, D. O. Obura, D. Ochavillo, B. A. Polidoro, W. F. Precht, M. C. Quibilan, C. Reboton, Z. T. Richards, A. D. Rogers, J. Sanciangco, A. Sheppard, C. Sheppard, J. Smith, S. Stuart, E. Turak, J. E. N. Veron, C. Wallace, E. Weil, \& E. Wood. 2008. One-third of reef-building corals face elevated extinction risk from climate change and local impacts. Science, 321(5888), 560-563.

Dalsgaard, T., D. E. Canfield, J. Petersen, B. Thamdrup, \& Jenaro Acuña-González. 2003. $\mathrm{N}_{2}$ production by the anammox reaction in the anoxic water column of Golfo Dulce, Costa Rica. Nature, 422(6932), 606-608

Mora, C., O. Aburto-Oropeza, A. Ayala Bocos, P. M. Ayotte, S. A. Banks, A. G. Bauman, M. Beger, S. Bessudo, D. J. Booth, E. Brokovich, A. Brooks, P. Chabanet, J. Cinner, Jorge Cortés-Núñez, J. J. Cruz-Motta, A. Cupul Magaña, E. DeMartini, G. J. Edgar, D. A. Feary, S. C. A. Ferse, A. M. Friedlander, K. J. Gaston, C. Gough, N. A. J. Graham, A. Green, H. M. Guzmán-Espinal, M. Hardt, M. Kulbicki, Y. Letourneur, A. López Pérez, M. Loreau, Y. Loya, C. Martínez, I. Mascareñas-Osorio, T. Morove, M. O. Nadon, Y. Nakamura, G. Paredes, N. Polunin, M. S. Pratchett, H. Reyes-Bonilla, F. Rivera, E. Sala, S. Sandin, G. Soler, R. Stuart-Smith, E. Tessier, D. P. Tittensor, M. Tupper, P. Usseglio, L. Vigliola, L. Wantiez, I. Williams, S. K. Wilson, \& F. A. Zapata. 2011. Global human footprint on the linkage between biodiversity and ecosystem functioning in reef fishes. PLoS Biol, 9(4).

Cortés-Núñez, Jorge \& M. J. Risk. 1985. A reef under siltation stress: Cahuita, Costa Rica. Bulletin of Marine Science, 36(2), 339-356.

Glynn, P. W., N. J. Gassman, C. M. Eakin, Jorge Cortés-Núñez, D. B. Smith, \& H. M. GuzmánEspinal. 1991. Reef coral reproduction in the eastern Pacific: Costa Rica, Panama, and Galápagos Islands (Ecuador), Part I Pocilloporidae. Marine Biology, 109(3), 355-368.

Paddack, M.J., J. D. Reynolds, C. Aguilar, R. S. Appeldoorn, J. Beets, E. W. Burkett, P. M. Chittaro, K. Clarke, R. Esteves, Ana C. Fonseca-Escalante, G. E. Forrester, A. M. Friedlander, J. García-Sais, G. González-Sansoón, L. K. B. Jordan, D. B. McClellan, M. W. Miller, P. P. Molloy, P. J. Mumby, I. Nagelkerken, M. Nemeth, R. Navas-Camacho, J. Pitt, N. V. C. Polunin, M. C. Reyes-Nivia, D. R. Robertson, A. Rodríguez-Ramírez, Eva Salas, S. R. Smith, R. E. Spieler, M. A. Steele, I. D. Williams, C. L. Wormald, A. R. Watkinson, \& I. M. Côté. 2009. Recent region-wide declines in Caribbean reef fish abundance. Current Biology, 19, 590-595.

Between 2000 and 2010, most articles on Costa Rican biodiversity published in the RBT (54.4\%) were written in English and $45.6 \%$ in Spanish (Nielsen-Muñoz, Azofeifa-Mora, \& Monge-Nájera, 2012). These percentages coincide well with those for the general productivity of CIMAR during 1979-2015 analyzed herein.

Thus, it is not surprising that $58.3 \%$ of the CIMAR-contributions have been published in English. However, the fact that a substantial portion of the articles $(41.7 \%)$ have been published in Spanish may suggest that (1) the main audience is in Latin America and that there is no need to publish in English, and (2) many researchers of the CIMAR feel more comfortable to publish in their native language.

In the case of the journals, almost half of all the articles of CIMAR were published in the RBT. This journal was founded in 1963 in the UCR to disseminate the results of studies related to tropical biology. Therefore, it is not surprising that the researchers of CIMAR tend to select this journal for their publications. One of the preferred ways to publish the results 
has been the publication of supplements of the RBT. During the study period (1979-2015), CIMAR-associated researchers were scientific editors of a total of 34 supplements. One example is the series of special issues (I-V) published under the title "Ecosistemas Acuáticos de Costa Rica-Costa Rica Aquatic Ecosystems" during the years 1998 and 2008, which contained a total of 110 articles and 81 authored by researchers with a CIMAR-affiliation. The use of RBT-supplements is an effective way to publish the research results of CIMAR, and additional analyses are recommended to evaluate the impact of these supplements in the national and international scientific community.

\section{Authorship and authors' productivity}

During its 36 years since its foundation and until 2015, CIMAR has published 624 contributions with an average of 17 articles per year. The average of the last two years (2014-2015) is 43.5 with a total of 19 affiliated researchers, 4 collaborators and 9 visiting researchers. These values can be compared to those of the Instituto Clodomiro Picado (ICP), another highly productive research center of the UCR. For 40 years (1970-2010) the ICP published on average 11 contributions per year, but the current average fluctuates around 25 papers per year for a group comprised by 19 researchers (Lomonte, 2012). On a regional level, the number of science and engineering articles credited to Latin American authors almost tripled between 1988 and 2001, significantly outpacing authors of other developing regions (http://www.nsf.gov/sbe/srs/infbrief/ nsf04336/start.htm).

The authors' productivity calculated in this study did not consider the number of years associated to CIMAR. Highly productive researchers may have joint the CIMAR recently or include senior researchers that may have accumulated many publications during the entire study period (1979-2015). Another factor, not considered in this study, is the number of working hours officially dedicated to research. A much more detailed study is necessary to assess the actual productivity of each individual researcher affiliated to CIMAR. Therefore, the data herein presented regarding the publication records should be interpreted with caution and provide just a rough estimate about the scientific productivity of the investigators of the CIMAR.

Another aspect, which may have supported the rising productivity, is the increasing capability of the researchers associated to CIMAR to access international funds, which provides an important strengthening to the limited funds provided by the Vice-Rectory for Research of the UCR. CIMAR has a highly trained and specialized staff that has gained experience and is contributing to the implementation and critical evaluation of Costa Rica's science, technology and innovation policies through interdisciplinary research and the development of institutional and professional capacities in a framework of dialogue and public-private agreements.

\section{Collaboration}

The publication record analyzed revealed a clearly international orientation of CIMAR. Just $9.6 \%$ of the articles have been authored with colleagues from national institutions, while most of the published contributions presented collaborations with authors from foreign institutions. The USA (since 1983) and Germany (since 1981) were the countries with the highest number of collaborations, which probably is related to the fact that a high number of CIMAR-researchers did their graduate studies in these two countries. Also, many projects were managed through bilateral or multilateral agreements, which promoted internships of foreign researchers, which in turn strengthened certain research areas of CIMAR.

A total of 267 articles (42.8\%) of CIMARpublications indicated foreign affiliations. These data can be compared to those of the Instituto Clodomiro Picado, founded in 1970 and being another consolidated research center of the University of Costa Rica. Since 1990 there has also been a clear trend towards publication with co-authors from other countries, 
and this tendency reached values of $70-75 \%$ on average in the most recent decade (2000-2010) (Lomonte, 2012).

\section{Research topics}

Most research published by CIMAR has been on marine topics. This result is not surprising considering that few CIMAR researchers work in limnology, and the most productive researchers cover almost exclusively marine topics. Studies about the Pacific of Costa Rica predominated, which is probably related to the fact that it harbors two important gulfs, Golfo de Nicoya and Golfo Dulce (see below). Moreover, fishing activities are concentrated along this coast, representing one of the principal economic activities for the communities (Espinoza \& Nielsen, 2006; Wehrtmann \& Nielsen-Muñoz, 2009). Jorge Campos and his collaborators from CIMAR published in the 1980s on fishery-related aspects (e.g., Campos, 1983), and Ingo S. Wehrtmann has been publishing about this topic in the last decade. One milestone for this research topic was the foundation of the Unidad de Investigación Pesquera y Acuicultura (UNIP) of the CIMAR in September 2007, which has generated numerous projects and publications, especially regarding deepwater bottom-trawl shrimp fishery and its bycatch (e.g., Wehrtmann \& Nielsen-Muñoz, 2009; Clarke, Espinoza, Ahrens, \& Wehrtmann, 2016; Villalobos-Rojas, Azofeifa-Solano, Camacho-García, \& Wehrtmann, 2017).

An important contributor was the late William A. Bussing (until 2014, the year he passed away). He is considered as the founder of ichthyological studies in Costa Rica, one of the most recognized ichthyologists in Latin America and international expert of the fish fauna, both marine and freshwater of Central America.

The most studied area along the Pacific of Costa Rica was the Golfo de Nicoya, followed by Isla del Coco, Golfo Dulce and Isla del Caño. The relative spatial proximity of the Golfo de Nicoya to the main campus of the UCR in San José and the presence of the field station "Estación Nacional de Ciencias
Marino-Costeras" situated in Punta Morales has contributed to its importance as a study area. This station has served as a basis for a series of (international) research projects, which resulted in numerous publications (see Wolff, Chavarría-Chaves, \& Vargas-Zamora, 1998). The importance of Golfo de Nicoya is related to the fact that it represents the most important fishing ground in the country (Cortés \& Wehrtmann, 2009), housing many fish species of considerable economic value that are targeted by the artisanal and partly semi-industrial fisheries of the region (Araya, 1984). Furthermore, this gulf is considered as the best-studied tropical estuary in the world (Vargas \& Mata, 2004).

The second most studied area is Isla del Coco. During the last years (2001-2015), publications (including three supplements of the RBT) about this oceanic island have increased substantially, and most of these contributions were associated with scientific expeditions led by Jorge Cortés and with funds provided by the Vice Rectory for Research of the UCR, the French Fund for the World Environment, the National Council of Presidents of the Public Universities of Costa Rica (CONARE), Conservation International, the Undersea Hunter Group as well as other funding agencies.

Golfo Dulce is another location that has been extensively studied by CIMAR personnel. It is a unique site because it is the only tropical fjord-like embayment (Hebbeln, Beese, \& Cortés, 1996; Hebbeln \& Cortés 2001; Dalsgaard, Canfield, Petersen, Thamdrup, \& Acuña-González, 2003) along the American Pacific Ocean and one of the four tropical fjords worldwide (Quesada-Alpízar, 2006). Moreover, the Golfito Campus of the University of Costa Rica, which was founded in 2006, has contributed to the development of research activities, outreach projects and teaching in the gulf area.

During the study period (1979-2015), research of CIMAR has focused on benthos, coral reefs and pelagic systems. When analyzing the contributions on animals, publications about invertebrates were more frequent than 
those about vertebrates, and topics such as taxonomy, ecology, oceanography, and meteorology were predominant. These tendencies are closely related to the specialty of the researchers affiliated with CIMAR and corroborate the findings of Cortés and Nielsen (2002) who analyzed the contributions on marine science published for 50 years (1963-2002) in the RBT, where the most-covered topic was ecology, followed by papers on biogeography (including all contributions about range extensions), parasitism, taxonomy, fisheries, and aquaculture. According to Cortés and Nielsen (2002), the most studied marine ecosystems were coral reefs and mangroves, and contributions about fishes, followed by mollusks, crustaceans and annelids were predominant during the study period (1963-2002). Considering that most of the scientific articles of the CIMAR-staff have been published in RBT, it is not surprising that the conclusions of Cortés and Nielsen (2002) are in general agreement with our results.

The preference for studying certain taxonomic groups and ecosystems is based on the specialty of the CIMAR-staff. However, projects about deepwater ecosystems (through expeditions organized by Jorge Cortés) and deepwater fishing (led by Ingo Wehrtmann) have opened new lines of research. In July 2015, the Laboratory of Genetics and Molecular Biology of Aquatic Organisms was inaugurated as a part of CIMAR. This laboratory, financed by UCR with roughly US\$ 200000 , is coordinated by Yolanda Camacho and Cindy Fernández (https://www.ucr.ac.cr/noticias/2015/07/30/ con-nuevo-laboratorio-la-ucr-hara-analisisgenetico-de-organismos-acuaticos.html). This laboratory provides new research opportunities and it might be expected that the number of publications including molecular analyses of marine and freshwater organisms of Costa Rica will soon increase.

In conclusion, CIMAR shows a high degree of internationalization in scientific production. Costa Rica published $25 \%$ of its articles in the most prestigious journal in the world (called first quartile or Q1). Nielsen \& Azofeifa (2013) reported that $39.8 \%$ for the scientific and technological publications of Costa Rica were included in the Scopus database.

Bibliometrics were useful for analyzing the productivity of a research center such as CIMAR. However, the national, regional and international importance of a research institution cannot be measured exclusively by the number of published papers; other aspects must be considered such as the impact factors of journals, the number of master and doctoral theses defended as well as the teaching and administrative loads of each staff members need to be considered when evaluating university departments (Giske, 2008). Therefore, future studies should include these factors to obtain a more realistic view about the productivity of an academic research center.

\section{RESUMEN}

Bibliometría de las publicaciones en ciencias marinas y limnología (1979-2015) del Centro de Investigación en Ciencias del Mar y Limnología (CIMAR), Universidad de Costa Rica. La bibliometría juega un papel importante en la evaluación de la producción científica de revistas y unidades de investigación, como universidades y centros de investigación. El presente estudio tuvo como objetivo analizar la producción científica del CIMAR desde su fundación en 1979 hasta 2015. Analizamos exclusivamente los artículos publicados en revistas internacionales y seleccionamos aquellos con al menos un autor afiliado al CIMAR. Para el análisis, clasificamos cada artículo según el área geográfica del estudio, el tema de la investigación, el ecosistema y el grupo taxonómico, y analizamos las siguientes variables: año de publicación, idioma, nombre de la revista y autores. También estimamos la distribución de Bradford, la citación, el factor de impacto y los cuartiles en los que se ubican las revistas utilizadas para publicar. El CIMAR produjo durante este período un total de 791 publicaciones. De ellas, 624 fueron artículos, 90 capítulos de libros o libros, 48 folletos y 34 Suplementos de la Revista de Biología Tropical (RBT). El número de publicaciones mostró una tendencia creciente durante el período de estudio, la mayoría de artículos fueron escritos en inglés $(58.3 \%)$ y $41.7 \%$ en español. Se seleccionaron un total de 128 revistas para publicar las contribuciones del CIMAR. Según el método de Bradford, la revista RBT, publicada por la Universidad de Costa Rica, se encuentra en la Zona I (mayor productividad o concentración), con el $49.8 \%$ de la producción científica total. En relación con la autoría, 22 autores publicaron 12 artículos o más y el $80 \%$ han sido publicados por autores con un bajo nivel de productividad (42 autores) y medio nivel de 
productividad (44 autores). CIMAR publicó $81.60 \%$ sobre temas marinos y $18.4 \%$ sobre limnología. La mayoría de los artículos (51.9\%) se referían al Pacífico de Costa Rica, el $13.5 \%$ al Caribe y el $34.7 \%$ a otros lugares de estudio. Las publicaciones del CIMAR se referían principalmente a estudios sobre ecología (33.3\%), taxonomía (24.5\%) y oceanografía/meteorología $(12.7 \%)$. Costa Rica muestra un alto grado de internacionalización en la producción científica. CIMAR tiene un personal altamente capacitado y especializado que ha adquirido mucha experiencia y está contribuyendo en la implementación y evaluación de las políticas de ciencia, tecnología e innovación de Costa Rica a través de la investigación interdisciplinaria y el desarrollo de capacidades institucionales y profesionales en un marco de diálogo y acuerdos público - privados.

Palabras clave: bibliometría, productividad de autor, análisis cientométricos, Costa Rica, CIMAR, Índice de Colaboración, temas de investigación, citación, América Latina.

\section{REFERENCES}

Araújo, R. J., \& Shideler, G. (2011). Celebrating 60 years of publication of the Bulletin of Marine Science: a bibliometric history (1951-2010). Bulletin of Marine Science, 87(4), 707-726.

Araya, H. A. (1984). Los sciaénidos (corvinas) del Golfo de Nicoya, Costa Rica. Revista de Biología Tropical, 32, 179-196.

Bornmann, L., Mutz, R., Neuhaus, C., \& Daniel, H. D. (2008). Citation counts for research evaluation: standards of good practice for analyzing bibliometric data and presenting and interpreting result. Ethics in Science and Environmental Politics, 8, 93-102.

Butler, L. (2008). Using a balanced approach to bibliometrics: quantitative performance measures in the Australian Research quality framework. Ethics in Science and Environmental Politics, 8, 83-92.

Campos, J. A. (1983). Talla de los peces descartados de la fauna de acompañamiento del camarón como un indicador de su posible utilización. Revista de Biología Tropical, 31(2), 209-212.

Chinchilla-Rodríguez, Z., Benavent-Pérez, M., \& de Moya-Anegón, F. (2012). International collaboration in medical research in Latin America and the Caribbean (2003-2007). Journal of the American Society for Information Science and Technology, 63(11), 2223-2238.

Chiroque, R. \& Medina, A. (2003). El SIDA y su productividad científica en la base de datos SciELO entre 1997 - 2003. Biblios, 16, 81-92.

Clarke, T. M., Espinoza, M., Ahrens, R., \& Wehrtmann, I. S. (2016) Elasmobranch bycatch associated with the shrimp trawl fishery off the Pacific coast of Costa Rica, Central America. Fishery Bulletin, 114, 1-17.

Colantonio, L. D., Baldridge, A. S., Huffman, M. D., Bloomfield, G. S., \& Prabhakaran, D. (2015). Publicações de pesquisas cardiovasculares da América Latina entre 1999 e 2008 . Um estudo bibliométrico. Arquivos Brasileiros de Cardiologia, 104(1), 5-15.

Cortés, J., \& Nielsen, V. (2002). Las ciencias del mar en la Revista de Biología Tropical en su 50 aniversario. Revista de Biología Tropical, 50(3/4), 903-907.

Cortés, J., \& Wehrtmann, I. S. (2009). Diversity of marine habitats of the Caribbean and Pacific of Costa Rica. In I. S. Wehrtmann and J. Cortés (Eds.). Marine Biodiversity of Costa Rica, Central America (pp. 1-45). Berlin, Germany: Springer.

Dalsgaard, T., Canfield, D. E., Petersen, J., Thamdrup, B., \& Acuña-González, J. (2003). $\mathrm{N}_{2}$ production by the anammox reaction in the anoxic water column of Golfo Dulce, Costa Rica. Nature, 422(6932), 606-608.

De Arenas, J. L., Arenas, M., \& Valles, J. (2002). La píldora anticonceptiva en América Latina y el Caribe. Estudio bibliométrico. Anales de Documentación, 5, 213-222.

De Filippo, D., Córdoba-González, S., \& Sanz-Casado, E. (2016). Bibliometría de la colaboración e impacto de la Revista de Biología Tropical (Web of Science 2003-2012). Revista de Biología Tropical, 64(1), 147-156.

Espinoza, M., \& Nielsen, V. (2006). Capítulo VII, Especies Comerciales I: Peces. In V. Nielsen-Muñoz \& M. A. Quesada-Alpízar (Eds.). Ambientes Marino Costeros de Costa Rica. Comisión Interdisciplinaria Marino Costera de la Zona Económica Exclusiva de Costa Rica (Informe Técnico) (pp. 87-104). San José, Costa Rica: CIMAR, CI, TNC.

Fernández, M. T., Gómez, I., \& Sebastián, J. (1998). La cooperación científica de los países de América Latina a través de indicadores bibliométricos. Interciencia, 23(6), 328-337.

Fourqurean, J. W., Duarte, C. M., Kershaw, M. D., \& Threlkeld, S. T. (2008). Estuaries and coasts as an outlet for research in coastal ecosystems: A bibliometric study. Estuaries and Coasts, 31, 469-476.

Giske, J. (2008). Benefitting from bibliometry. Ethics in Science and Environmental Politics, 8, 79-81.

Gorbea, (2005). Modelo teórico para el estudio métrico de la información documental. Gijón, Spain: Trea.

Hebbeln, D., \& Cortés, J. (2001). Sedimentation in a tropical fjord: Golfo Dulce, Costa Rica. Geo-Marine Letters, 20, 142-148. 
Hebbeln, D., Beese, D., \& Cortés, J. (1996) Morphology and sediment structures in Golfo Dulce, Costa Rica. Revista de Biología Tropical, 44(Suppl. 3), 1-10.

Lawrence, P. A. (2008). Lost in publications: how measurement harms science. Ethics in Science and Environmental Politics, 8, 9-11.

Leimkuhler, F. F. (1967). The Bradford distribution. Journal of Documentation, 23(3), 197-207.

Lima, R. A. de, Velho, L., \& Faria, L. I. L. (2007). Indicadores bibliométricos de cooperação científica internacional em bioprospecção. Perspectivas em Ciência da Informação, 12, 50-64.

Lomonte, B. (2012). Scientific and technological research at the Instituto Clodomiro Picado: A bibliometric perspective of four decades (1970-2010). INTERCIENCIA, 37(6), 424-430.

Lomonte, B., \& Ainsworth, S. (2002). Publicaciones científicas de Costa Rica en el Science Citation Index: análisis bibliométricos del trienio 1999-2001. Revista de Biología Tropical, 50, 951-962.

Medina, I. F., \& Páramo, P. (2014). La investigación en educación ambiental en América Latina: un análisis bibliométrico. Revista Colombiana de Educación, $66,19-72$.

Michán, L., \& Llorente-Bousquets, J. (2010). Bibliometría de la sistemática biológica sobre América Latina durante el siglo XX en tres bases de datos mundiales. Revista de Biología Tropical, 58(2), 531-545.

Monge-Nájera, J., \& Ho, Y. H. (2012). Costa Rica publications in the Science Citation Index Expanded: A bibliometric analysis for 1981-2010. Revista de Biología Tropical, 60(4), 1649-1661.

Monge-Nájera, J., \& Ho, Y. H. (2016). Bibliometry of the Revista de Biología Tropical / International Journal of Tropical Biology and Conservation: document types, languages, countries, institutions, citations and article lifespan. Revista de Biología Tropical, 64(3), 1223-1235.

Monge-Nájera, J., \& Nielsen, V. (2005). The countries and languages that dominate biological research at the beginning of the 21 st century. Revista de Biología Tropical, 53, 283-294.

Monge-Nájera, J., Nielsen-Muñoz, V., \& Azofeifa, A. B. (2010). Determinants of scientific output: an in-depth view of the productivity of tropical botanist and conservationist, Luis Diego Gómez Pignataro. Revista de Biología Tropical, 58, 1093-1114.

Monge-Nájera, J., Nielsen-Muñoz, V., \& Azofeifa-Mora, A. B. (2013). Subject and authorship of records related to the Organization for Tropical Studies (OTS) in BINABITROP, a comprehensive database about
Costa Rican biology. Revista de Biología Tropical, 61(2), 493-500.

Nielsen, V., \& Azofeifa, A. B. (2013). Análisis de la producción científico-tecnológica en Costa Rica: 2001 2011. In M. Santos \& I. García (Eds.). Ponencia para el Primer Informe sobre el Estado de la Ciencia, la Tecnología y la Innovación. 2014. Programa Informe Estado de la Nación, Costa Rica. http://www.estadonacion.or.cr/ecti/assets/produccion_cientifica_y_tecnologica.pdf

Nielsen-Muñoz, V., Azofeifa-Mora, A. B., \& Monge-Nájera, J. (2012). Bibliometry of Costa Rica biodiversity studies published in the Revista de Biología Tropical/ International Journal of Tropical Biology and Conservation (2000-2010): the content and importance of a leading tropical biology journal in its 60th anniversary. Revista de Biología Tropical, 60(4), 1405-1413.

Praunlich, P., \& Kroll, M. (1978). Bradford's distribution: A new formulation. Journal of the American Society for Information Science, 29, 51-55.

Quesada-Alpízar, M. A. (2006). Capítulo XVI, Conclusiones y recomendaciones finales. In V. Nielsen-Muñoz \& M. A. Quesada-Alpízar (Eds.). Ambientes Marino Costeros de Costa Rica (pp. 201-207). Comisión Interdisciplinaria Marino Costera de la Zona Económica Exclusiva de Costa Rica (Informe Técnico). San José, Costa Rica: CIMAR, CI, TNC.

Russell, J. M., Ainsworth, S., del Río, J. A., Narváez-Berthelemot, N., \& Cortés, H. D. (2007). Colaboración científica entre países de la región latinoamericana. Revista Española de Documentación Científica, 30(2), 180-198.

Saavedra-Fernández, Ó., Sotolongo-Aguilar, Guzmán Sánchez, M. V. (2002). Medición de la producción científica en América Latina y el Caribe en el campo agrícola y afines: un estudio bibliométrico. Revista Española de Documentación Científica, 25(2), 151-161.

Spinak, E. (1996). Diccionario enciclopédico de bibliometría, cienciometría e informetría. Caracas, Venezuela: UNESCO-CII/II

Tinoco, C. F., Lima, N. E., Lima-Ribeiro, M. S., \& R. G. Collevatti. (2015). Research and partnerships in studies on population genetics of Neotropical plants: A scientometric evaluation. Biochemical Systematics and Ecology, 61, 357-365.

Vargas, J. A., \& Mata, A. (2004). Where the dry forest feeds the sea: The Gulf of Nicoya estuary. In G. W. Frankie, A. Mata \& S. B. Vinson (Eds.). Biodiversity conservation in Costa Rica; Learning the lessons in a seasonal dry forest (pp. 126-135). California, USA: University of California Press.

Vera-Polania, F., Perilla-Gonzalez, Y., Martinez-Pulgarin, D. F., Baquero-Rodríguez, J. D., Munoz-Urbano, 
M., Lagos-Gallego, M., ... Rodríguez-Morales, A. J. (2014). Bibliometric assessment of the LatinAmerican contributions in dengue. Recent Patents on Anti-infective Drug Discovery, 9(3), 195-201.

Villalobos-Rojas, F., Azofeifa-Solano, J. C., CamachoGarcía, Y E., \& Wehrtmann, I. S. 2017. Gastropods and bivalves taken as by-catch in the deep-water shrimp trawl-fishery along the Pacific coast of Costa Rica, Central America. Molluscan Research, 37(3), 175-186.

Wehrtmann, I. S., \& Nielsen-Muñoz, V. (2009). The deepwater $r$ fishery along the Pacific coast of Costa Rica, Central America. Latin American Journal of Aquatic Research, 37(3), 543-554.
Wolff, M., Chavarría-Chaves, J. B., \& Vargas-Zamora, J. A. (1998). A trophic flow model of the Golfo de Nicoya, Costa Rica. Modelo de flujo trófico del Golfo de Nicoya, Costa Rica. Revista de Biología Tropical, 46(Suppl. 6), 63-79.

Wulff, E. (2008). Sesenta añoi de botánica marina (19462006): criterios informacionales y sugerencias. Digital. CSIC. Ciencia en abierto (http://hdl.handle. net/10261/6344).

Zakutina, G. P., \& Priyenikova, V. K. (1983). Caracteristicas y análisis del flujo de los documentos primarios. La Habana, Cuba: IDICT. 


\section{APPENDIX 1}

Scientific articles produced by CIMAR between 1979 and 2015 .

Distribution by country of publications in the 128 journals

\begin{tabular}{|c|c|c|c|}
\hline Country & Number of Journals & Number of Articles & Percentage \\
\hline Costa Rica & 20 & 386 & 61.9 \\
\hline United States & 29 & 61 & 9.8 \\
\hline Germany & 13 & 35 & 5.6 \\
\hline United Kingdom/England & 23 & 39 & 6.3 \\
\hline New Zealand & 1 & 19 & 3.0 \\
\hline Holland & 10 & 18 & 2.9 \\
\hline Mexico & 6 & 12 & 1.9 \\
\hline Spain & 4 & 9 & 1.4 \\
\hline Brazil & 3 & 8 & 1.3 \\
\hline Bulgaria & 1 & 8 & 1.3 \\
\hline Chile & 2 & 8 & 1.3 \\
\hline Philippines & 1 & 3 & 0.48 \\
\hline Canada & 1 & 2 & 0.32 \\
\hline Colombia & 2 & 2 & 0.32 \\
\hline Norway & 2 & 2 & 0.32 \\
\hline Puerto Rico & 1 & 2 & 0.32 \\
\hline Taiwan & 1 & 2 & 0.32 \\
\hline Australia & 1 & 1 & 0.16 \\
\hline Belgium & 1 & 1 & 0.16 \\
\hline China & 1 & 1 & 0.16 \\
\hline South Korea & 1 & 1 & 0.16 \\
\hline France & 1 & 1 & 0.16 \\
\hline Japan & 1 & 1 & 0.16 \\
\hline Panama & 1 & 1 & 0.16 \\
\hline Poland & 1 & 1 & 0.16 \\
\hline Total & 128 & 624 & 100 \\
\hline
\end{tabular}




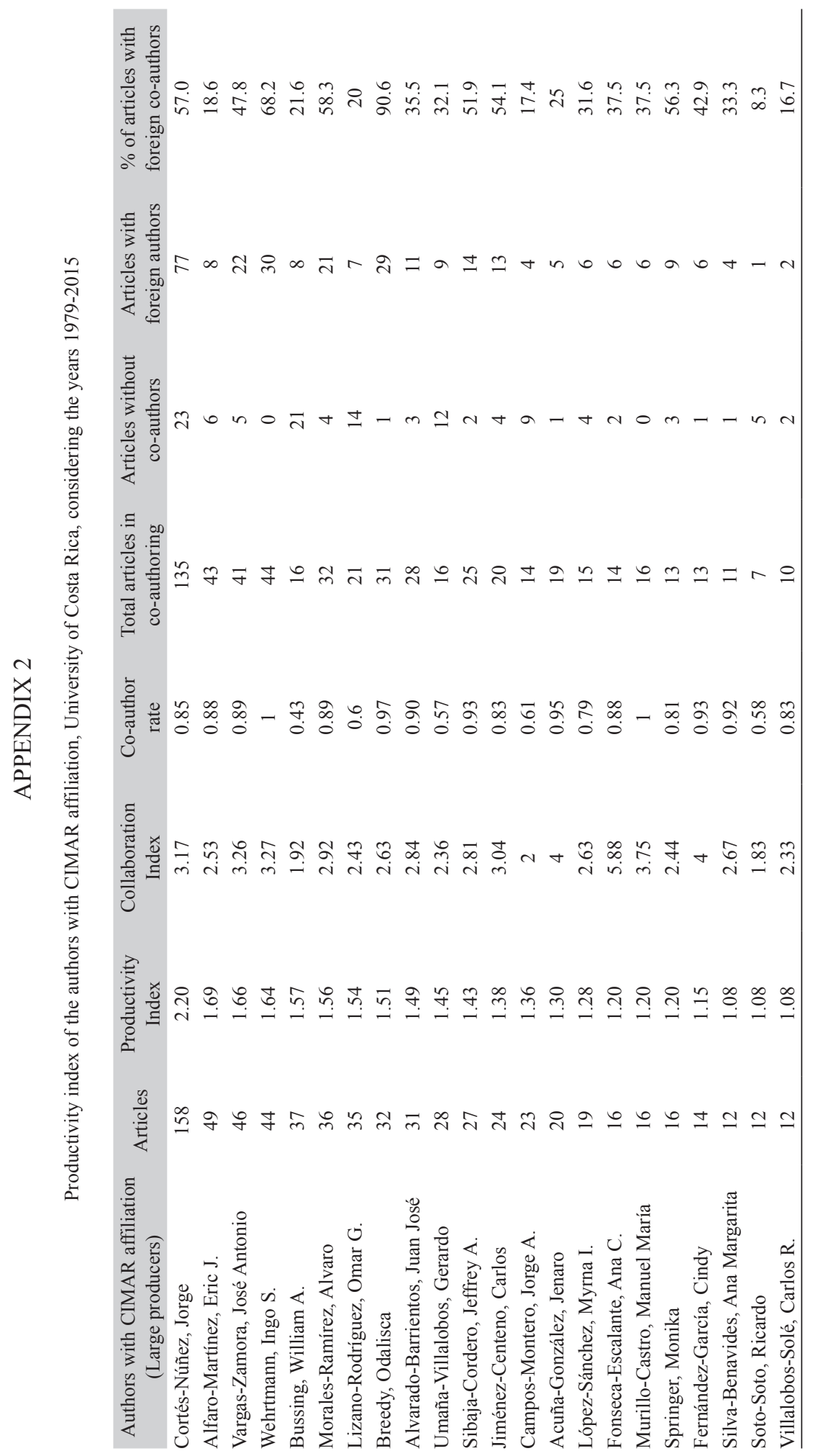




\section{APPENDIX 3}

CIMAR articles (1979-2015) with foreign co-authors and years in which this collaboration took place

\begin{tabular}{|c|c|c|c|c|}
\hline Country & Affiliations & Authors & Articles & Year or Range of years \\
\hline United States & 79 & 113 & 87 & $1983-2015$ \\
\hline Panama & 2 & 8 & 39 & $1987-2015$ \\
\hline Mexico & 17 & 30 & 35 & 2001-2015 \\
\hline Germany & 12 & 24 & 34 & $1981-2015$ \\
\hline Brazil & 9 & 12 & 22 & 2009-2015 \\
\hline Spain & 8 & 21 & 21 & $2001-2015$ \\
\hline Chile & 7 & 17 & 13 & $2008-2015$ \\
\hline Puerto Rico & 5 & 7 & 10 & $1986,1993 / 2010-2015$ \\
\hline United Kingdom & 10 & 11 & 9 & $1996,2008-2015$ \\
\hline Australia & 3 & 4 & 7 & 2008-2015 \\
\hline Canada & 4 & 5 & 7 & $1980-1985 / 2006-2015$ \\
\hline Argentina & 3 & 3 & 6 & 2009-2015 \\
\hline Colombia & 7 & 8 & 5 & 2007-2015 \\
\hline France & 13 & 11 & 5 & $1982,1990 / 2010-2013$ \\
\hline Italy & 2 & 4 & 5 & 2008- 2014 \\
\hline Cyprus & 2 & 1 & 4 & 2012-2015 \\
\hline Nicaragua & 3 & 5 & 4 & 1994/2010-2011 \\
\hline Denmark & 2 & 3 & 3 & 2003-2014 \\
\hline Ecuador & 5 & 5 & 3 & 2009-2011 \\
\hline El Salvador & 2 & 2 & 3 & 1994-1995/2011 \\
\hline Holland & 4 & 5 & 3 & 2008-2015 \\
\hline Peru & 3 & 4 & 3 & 2009-2012 \\
\hline Uruguay & 2 & 1 & 3 & $2001-2008$ \\
\hline Belgium & 2 & 4 & 2 & 2013 \\
\hline Czech Republic & 3 & 3 & 2 & $2012-2013$ \\
\hline Poland & 2 & 2 & 2 & 1994, 1997 \\
\hline Barbados & 1 & 1 & 1 & 2014 \\
\hline Cuba & 1 & 1 & 1 & 2007 \\
\hline Guam & 1 & 1 & 1 & 1987 \\
\hline Israel & 1 & 3 & 1 & 2003 \\
\hline Jamaica & 1 & 1 & 1 & 2014 \\
\hline New Caledonia & 1 & 1 & 1 & 2013 \\
\hline Norway & 2 & 3 & 1 & 2006 \\
\hline Trinidad and Tobago & 1 & 1 & 1 & 2014 \\
\hline Venezuela & 1 & 1 & 1 & 2000 \\
\hline
\end{tabular}




\section{APPENDIX 4}

CIMAR articles (1979-2015) with co-authors from Costa Rican institutions and years in which this collaboration took place

\begin{tabular}{|c|c|c|c|}
\hline Costa Rican Affiliations & Authors & Articles & $\begin{array}{c}\text { Year or Range } \\
\text { of years }\end{array}$ \\
\hline Asesores Legales del Istmo, San José & 1 & 1 & 2012 \\
\hline Centro de Estudios de Antropología Aplicada, Golfito & 1 & 1 & 2004 \\
\hline Centro Nacional de Alta Tecnología & 2 & 2 & $2006-2010$ \\
\hline Compañía Nacional de Fuerza y Luz & 1 & 1 & 2015 \\
\hline Conservación Internacional & 1 & 1 & 2015 \\
\hline DeepSee, Under Sea Hunter Group, San José & 1 & 1 & 2012 \\
\hline FERTICA, Puntarenas & 1 & 1 & 1998 \\
\hline Fundación MarViva & 1 & 1 & 2012 \\
\hline Hábitat Crítico: Consultores Ambientales, San José & 1 & 2 & 2012 \\
\hline ICE. Centro de Servicio de Gestión Ambiental, San José & 1 & 1 & 2015 \\
\hline ICE. Proyecto Hidroeléctrico El Diquís & 2 & 3 & $2013-2015$ \\
\hline ICE. Departamento de Hidrología, Estudios Básicos de Ingeniería & 1 & 4 & 2012-2014 \\
\hline INCOPESCA. Dirección General Técnica, Puntarenas & 1 & 1 & 1998 \\
\hline INRECOSMAR, San José & 2 & 1 & 2001 \\
\hline Instituto Meteorológico Nacional & 1 & 5 & $2001-2013$ \\
\hline Instituto Meteorológico Nacional. Departamento de Meteorología Sinóptica & 1 & 1 & 2009 \\
\hline Laboratorio de Biomonitoreo Acuático AquaBioLab S. A. & 1 & 1 & 2014 \\
\hline MAG. Departamento de Pesca & 2 & 1 & 1993 \\
\hline MeRida S.A. Consultores Ambientales & 1 & 1 & 1998 \\
\hline MOP. Dirección General de Transporte Marítimo & 1 & 1 & 1986 \\
\hline Municipalidad de Mora & 1 & 1 & 2015 \\
\hline Museo Nacional & 1 & 6 & 1982-1992 \\
\hline Serpentario Nacional. San José & 1 & 1 & 2000 \\
\hline SINAC. Parque Nacional Carara, Tárcoles & 1 & 1 & 2014 \\
\hline SINAC. Programa Marino-Costero & 1 & 1 & 2011 \\
\hline SINAC. Reserva Natural Absoluta Cabo Blanco & 1 & 1 & 1998 \\
\hline The Nature Conservancy - Consultores & 3 & 2 & $2010-2011$ \\
\hline The Nature Conservancy. Región de Latinoamérica & 3 & 1 & 2011 \\
\hline UICN, San José & 1 & 1 & 2006 \\
\hline UNA. Escuela de Ciencias Ambientales & 1 & 1 & 1985 \\
\hline UNA. Escuela de Ciencias Biológicas & 8 & 12 & $1984-2015$ \\
\hline UNA. Escuela de Ciencias Biológicas, Laboratorio de Manglares y Ecología Estuarina & 1 & 1 & 1993 \\
\hline UNA. Escuela de Ciencias Geográficas & 1 & 1 & 2010 \\
\hline UNA. Estación de Ciencias Marinas & 1 & 1 & 1996 \\
\hline UNA. Posgrado en Sistemas de Información Geográfica y Teledetección & 1 & 1 & 2010 \\
\hline UNA. Programa de Maestría en Ciencias Marinas y Costeras & 1 & 1 & 2010 \\
\hline UNA. Instituto Regional de Estudios en Sustancias Tóxicas (IRET) & 1 & 1 & 2015 \\
\hline WWF, San José & 3 & 2 & 2010 \\
\hline
\end{tabular}




\section{APPENDIX 5}

CIMAR articles (1979-2015) with co-authors from UCR (research centers, schools, departments and faculties) and years in which this collaboration took place

\begin{tabular}{|c|c|c|c|}
\hline UCR institutions & Authors & Articles & Year or Range of years \\
\hline Centro de Investigación en Contaminación Ambiental (CICA) & 4 & 3 & $1987-2011$ \\
\hline Centro de Investigación en Estructuras Microscópicas (CIEMic) & 2 & 2 & $2007-2012$ \\
\hline Centro de Investigación y Diagnóstico en Parasitología (CIDPA) & 1 & 2 & 1989 \\
\hline Centro de Investigaciones Geofísicas (CIGEFI) & 11 & 17 & $1990-2015$ \\
\hline Escuela Centroamericana de Geología & 4 & 5 & $1998-2015$ \\
\hline Escuela de Biología & 29 & 40 & $1983-2015$ \\
\hline Escuela de Biología. Herbario & 1 & 1 & 2011 \\
\hline Escuela de Biología. Museo de Zoología & 7 & 10 & $1997-2014$ \\
\hline Escuela de Estadística & 1 & 2 & 2004-2015 \\
\hline Escuela de Estudios Generales & 1 & 1 & 2015 \\
\hline Escuela de Filología Lingüística y Letras & 1 & 1 & 2000 \\
\hline $\begin{array}{l}\text { Escuela de Física. Centro de Investigación en Ciencias Atómicas } \\
\text { Nucleares y Moleculares (CICANUM) }\end{array}$ & 3 & 2 & $2008-2012$ \\
\hline $\begin{array}{l}\text { Escuela de Física. Laboratorio de Ciencias Atmosféricas, } \\
\text { Oceanográficas y Planetarias }\end{array}$ & 1 & 1 & 1998 \\
\hline Escuela de Física. Laboratorio de Física Nuclear Aplicada & 1 & 1 & 2002 \\
\hline $\begin{array}{l}\text { Escuela de Física. Departamento de Física Atmosférica, } \\
\text { Oceánica y Planetaria }\end{array}$ & 2 & 2 & $1996-2004$ \\
\hline Escuela de Geografía & 1 & 1 & 2001 \\
\hline Escuela de Ingeniería Agrícola & 1 & 1 & 2009 \\
\hline Escuela de Ingeniería Eléctrica & 1 & 1 & 2010 \\
\hline Escuela de Química & 4 & 2 & $1998-2006$ \\
\hline Escuela de Tecnología de Alimentos & 1 & 1 & 1998 \\
\hline Facultad de Microbiología & 1 & 1 & 1994 \\
\hline Sede Universitaria de Occidente & 2 & 2 & $1993-2015$ \\
\hline Sistema de Estudios de Posgrado & 1 & 2 & 1984-1985 \\
\hline Sistema de Estudios de Posgrado en Biología & 5 & 6 & $2000-2012$ \\
\hline $\begin{array}{l}\text { Sistema de Estudios de Posgrado en Gestión Integrada de } \\
\text { Áreas Costeras Tropicales (GIACT) }\end{array}$ & 4 & 5 & 2004-2015 \\
\hline Unidad de Microscopía Electrónica & 2 & 2 & 1994- 2001 \\
\hline
\end{tabular}


APPENDIX 6

Citation of CIMAR articles in the Web of Science (1979 - 2015)

\begin{tabular}{|c|c|c|}
\hline Articles & Citation & $\%$ Articles \\
\hline 1 & 426 & 0.16 \\
\hline 1 & 399 & 0.16 \\
\hline 1 & 226 & 0.16 \\
\hline 1 & 197 & 0.16 \\
\hline 1 & 119 & 0.16 \\
\hline 1 & 112 & 0.16 \\
\hline 2 & 72 & 0.32 \\
\hline 1 & 64 & 0.16 \\
\hline 1 & 62 & 0.16 \\
\hline 1 & 59 & 0.16 \\
\hline 1 & 58 & 0.16 \\
\hline 1 & 53 & 0.16 \\
\hline 1 & 52 & 0.16 \\
\hline 1 & 51 & 0.16 \\
\hline 1 & 49 & 0.16 \\
\hline 1 & 47 & 0.16 \\
\hline 1 & 43 & 0.16 \\
\hline 1 & 40 & 0.16 \\
\hline 1 & 39 & 0.16 \\
\hline 1 & 37 & 0.16 \\
\hline 1 & 36 & 0.16 \\
\hline 4 & 35 & 0.64 \\
\hline 2 & 34 & 0.32 \\
\hline 4 & 32 & 0.64 \\
\hline 1 & 31 & 0.16 \\
\hline 1 & 29 & 0.16 \\
\hline 3 & 27 & 0.48 \\
\hline 5 & 26 & 0.80 \\
\hline 3 & 25 & 0.48 \\
\hline 1 & 24 & 0.16 \\
\hline 4 & 23 & 0.64 \\
\hline 3 & 22 & 0.48 \\
\hline 5 & 21 & 0.80 \\
\hline 1 & 20 & 0.16 \\
\hline 8 & 19 & 1.28 \\
\hline 1 & 18 & 0.16 \\
\hline 4 & 17 & 0.64 \\
\hline 8 & 16 & 1.28 \\
\hline 8 & 15 & 1.28 \\
\hline 6 & 14 & 0.96 \\
\hline 10 & 13 & 1.60 \\
\hline 15 & 12 & 2.40 \\
\hline 11 & 11 & 1.76 \\
\hline 12 & 10 & 1.92 \\
\hline 15 & 9 & 2.40 \\
\hline 16 & 8 & 2.56 \\
\hline 22 & 7 & 3.53 \\
\hline 23 & 6 & 3.69 \\
\hline 23 & 5 & 3.69 \\
\hline 29 & 4 & 4.65 \\
\hline 34 & 3 & 5.45 \\
\hline 50 & 2 & 8.01 \\
\hline 56 & 1 & 8.97 \\
\hline 63 & 0 & 10.10 \\
\hline
\end{tabular}

